\title{
Student worksheet oriented on science, technology, engineering, and mathematics (STEM) with PjBL model on acid base matter by using natural product
}

\author{
Imtikhana Nur Khofifah', and Mitarlis ${ }^{1, *}$ \\ 'Department of Chemistry, Faculty of Mathematic and Natural Sciences, Universitas Negeri Surabaya, \\ 60231, Indonesia \\ *Corresponding author: M, mitarlis@unesa.ac.id
}

DOI: 10.24114/jpkim.v13i1.24141

Article history:

Received: 06 February 2021

Revised: 25 February 2021

Accepted: 25 February 2021

\begin{abstract}
This study aims to describe the feasibility of the student worksheet developed in improving critical, creative, collaborative, and communicative thinking skills of students on acid-base material by using natural product. The student worksheet developed refers to the project-based learning model, which is integrated to science, technology, engineering, and mathematics (STEM). Method of this study uses a 4-D model (define, design, develop and disseminate), which is limited only to the development stage, and limited trials are carried out to nine students at senior high school. The feasibility of student worksheet is viewed from three aspects, namely validity, practicality, and effectiveness. The validity is viewed from the results of content and construct validity. The results obtained on each criterion show that the percentage score of $92.95 \%$ and $91.15 \%$ on very good category. The student worksheet's practicality in terms of activity observation and student response for each component obtained a percentage score of $95.18 \%$ and $88.09 \%$ on very practical category. The student worksheet's effectiveness in terms of the completeness of student learning outcomes showed an increase in the average $\mathrm{N}$-Gain score of 0.84 on very high category and declared effective. Thus, the feasibility of the developed student worksheet in terms of all aspects such as percentage of scores obtained $\geq 61 \%$ in the aspects of validity, practicality and N-gain $\geq 0.3$ in the aspect of effectiveness. So, the developed students worksheet oriented to STEM with PjBL model on acid base matter by using natural product is feasible for use in the learning.
\end{abstract}

Keywords: acid-base, PjBL, STEM, student worksheet

\section{Introduction}

The Indonesia education paradigm provides an overview of ongoing learning process that integrated with technology (Hendayana, 2020). The rapid development of science and technology in the 21st century impacts on fierce competition in various 
fields, especially in field of education which is aimed improving the quality of human resources who can compete in the global era (Pratiwi et al. 2019). Good cooperation is needed in dealing with these demands. Besides, the curriculum is also used as a basis for developing learning innovations and preparing students to be communicative, collaborative, creative, innovative skills, as well as critical and analytical thinking to effectively solve real-world problems that are able to keep up with the needs of the times and times (Mitarlis et al. 2020).

The government's efforts to improve the quality of education in Indonesia by developing the mindset of students as stated in the 2013 Curriculum demands of 21st century competencies (Witri et al. 2020). Based on Permendikbud No. 36 of 2018, the 2013 curriculum requires students to be active during learning activities and expected to build their own knowledge (Kemendikbud, 2018). This curriculum also changes the mindset from teacher centered to be student centered. Teachers in the learning process not only provide information but also act as organizers and learning facilitators for students (Wahyono et al. 2020).

The world of education has changed due to COVID-19 outbreak which has hit almost all countries in the world. The government has made various policies to break the chain of spreading COVID-19, especially in education field. Referring to Circular Number 4 of 2020 concerning Education Implementation during COVID-19, the learning process implementation is carried out online (Kemendikbud, 2020).

Online learning is currently considered to be more centered on students which are able to increase the responsibility in learning, prepare their own learning, evaluate, organize, maintain motivation in learning, and increase student interest (Sadikin and Hamidah, 2020). According to Melania (2020) online learning makes students understand technology, be more creative in completing tasks, and condition themselves as comfortably as possible to learn without formal rules.

During online, the learning process implementation gives limited interaction between students and teachers, especially not all subjects can be implemented indirectly as in chemistry subjects. Chemistry is the study of the structure, changes in matter, and the energy that accompanies it. Chemistry learning emphasizes the development of skills, technology, and their application in everyday life (Permanasari, 2016). The chemistry implementation learning understands basic concepts to improve science skills and critical thinking. Chemistry is an experimental science that requires learning activities such as practicums or projects to help improve students' understanding.

Based on research, the Program for International Student Assessment (PISA) shows poor performance with high equity criteria related to STEM. Indonesia is ranked 63 in the mathematics sector out of 72 countries that are members of the OECD with an average score of 379 and ranked 62 for the field of science with an average score of 389 (OECD, 2018). The Indonesian students low ability in the fields of science and mathematics is caused by the use of learning methods and approaches 
that don't encourage critical thinking (STEM, 2020). The project based learning model is integrated with Science, Technology, Engineering, and Mathematics (STEM) approach which can organize research and student problems management (Mulyani, 2019).

STEM is an innovative learning approach designed to improve science skills, technology skills, engineering, and mathematics that are able to complete globally (Wisudawati, 2018). The STEM approach integrates four interdisciplinary, namely science, technology, engineering, and mathematics into a holistic unit based on the everyday life context in learning process (Bybee, 2013). Science requires mathematics as a data processing tool, while technology and engineering are science applications (Afriana et al. 2016). Learning that integrated with STEM consists of 4C, namely creativity, critical thinking, collaboration, and communication (Rahmatina et al. 2020). The integration of STEM aspects during learning activities will improve learning outcomes and scientific literacy.

Project Based Learning ( $\mathrm{PjBL}$ ) is a learning model that fits the STEM approach. $\mathrm{PjBL}$ focuses on student centered teaching activities by providing freedom to explore in planning learning activities and carrying out project tasks so as to produce a product (Ningtyas et al. 2019). Through PjBL, students can gain learning experiences that are learning to obtain concepts built based on the products produced. The application of PjBL is more appropriate in interdisciplinary learning because it involves many different academic skills, such as reading, writing, arithmetic, and building conceptual understanding (Afriana et al. 2016). Interactive learning with PjBL model is effective to improving student skills that can affect the acquisition of learning outcomes (Harefa et al. 2019; Silaban, 2021).

The appropriate teaching materials must support learning models use, such as student worksheets (Prastowo, 2014). Student worksheet is defined as sheets containing tasks that students must complete, usually in the form of instructions or steps to complete a task referring to Basic Competencies and Learning Indicators that must be achieved (Depdiknas, 2008). The use of student worksheet in the learning activities is essential to improve the quality of learning.

The pre-research results conducted at SMAN 1 Gedangan, as many as $71 \%$ of students revealed that the teaching materials commonly used student worksheet. As many as $79 \%$ of students have heard of STEM, but have never received a student worksheet that is integrated with the STEM aspect. This is not in line with skillsoriented teaching materials at 21st century according to the 2013 Curriculum, which contains creative and innovative aspects through multidisciplinary learning and critical thinking (Kemendikbud, 2018). One of the chemical materials that apply these skills is acid-base material.

Acid-base matter is a material that is closely related to everyday life. This accordance with the PjBL learning used in this study, namely by utilizing natural product as an acid-base indicator. Natural product used as indicators are generally 
easy to find in the environment. The use of natural product in acid-base learning can facilitate the implementation of the learning process, first in the conditions of the COVID-19 pandemic, which requires online learning implementation. The use of natural product in learning is also an effort to support creating an environment with a Green Chemistry insight. Based on Mitarlis et al. (2018) the concept of Green Chemistry is a product innovation design that is oriented towards the coloring levels and stages of dangerous substances. The efforts to support this innovation can be realized by using acid indicators from natural product integrated with STEM aspects.

The action needed from the STEM-oriented student worksheet development research using PjBL model based on the description above. This study aims to describe the feasibility of the developed student worksheet, covering three aspects, namely validity, practicality, and effectiveness.

\section{Methods}

\subsection{Research Design}

The student worksheet development type refers to the Four-D method (4-D) research designed by Thiagarajan and Semmel. The 4-D model consists stages (1) define, (2) design, (3) develop, and (4) disseminate. This study aims to know the student worksheet feasibility development (Ibrahim and Wahyukartiningsih, 2014).

\subsection{Research Subject}

Research subject was need at stage of limited research trials. It had been done at SMAN 1 Gedangan to nine students of class XI IPA who were selected heterogeneously based on their academic abilities and small group form. According to Vygotsky's theory, students can learn through interaction and help from other peers who experts (Slavin, 2011).

\subsection{Data Collection Techniques and Instruments}

Feasibility of student worksheet in terms of validity, practicality, and effectiveness (Nieveen and Theerjd, 2010). The data technique that used in this study by review sheet instruments and validation sheets to assess the validity, then the activity observation sheet instruments and student questionnaires to assess the student worksheet practicality and effectiveness which was viewed from the student learning outcomes completeness through the pretest and posttest scores.

\subsection{Data Analysis}

The student worksheet validity was carried out by two chemistry lecturers and one chemistry teacher who gave scores for each criterion assessment of content validity and construct validity (presentation, language, graphic). The validation results were analyzed descriptively quantitatively using a Likert scale. Furthermore, it 
is calculated to obtain the validity by comparing the scores obtained number and the score criteria. It is the calculation of the highest score $x$ the number of aspects $x$ the number of validators. After obtaining the percentage of validity, interpretation is carried out according to the criteria in Table 1.

Table 1

Validation Result Score Interpretation

\begin{tabular}{c|c}
\hline Percentage (\%) & Category \\
\hline $0-20$ & Very Invalid \\
\hline $21-40$ & Invalid \\
\hline $41-60$ & Enough \\
\hline $61-80$ & Valid \\
\hline $81-100$ & Very Valid \\
\hline
\end{tabular}

Table 2

$\mathrm{N}$-Gain Score Interpretation

\begin{tabular}{c|c}
\hline Score & Category \\
\hline$g<0.3$ & Low \\
\hline $0.7 \geq g \geq 0.3$ & Medium \\
\hline$g>0.7$ & High \\
\hline
\end{tabular}

Student worksheet that has validated and declared fit for use, then a limited trial can be carried out. The data obtained from the results of the limited trial of students observations and students can be used to see the feasibility of student worksheet in the practical aspect. Data analysis was performed using the Guttman scale, then obtained the student worksheet practical. Student worksheet developed is declared to be practicality if reaches $\geq 61 \%$ (Riduwan, 2016).

The aspect of effectiveness in terms of completeness of learning outcomes through the pretest and posttest was analyzed using an $\mathrm{N}$-gain score to see the increase in students ability before and after learning using student worksheet STEMPjBL. The increase in learning outcomes obtained by students is interpreted according to the criteria in Table 2. Student worksheet developed is declared to be effective if the results of the increase minimum value of $0.7 \geq g \geq 0.3$ in the medium category (Hake, 1999).

\section{Results and Discussion}

This study aims to describe the feasibility of the developed student worksheet in terms of its validity, practicality, and effectiveness. The developed student worksheet results are STEM oriented student worksheet and the learning refers to the stages of the PjBL model. The student worksheet development process uses a 4-D model with four stages that only carried out until develop stage. 


\subsection{Define Stage}

This stage aims to define and determine the conditions of learning by analyzing the limitations of materials in the context of developing teaching materials. Several analyzes that must be passed before designing and developing student worksheet include by front end analysis, task analysis, student analysis, material analysis, and formulation of learning objectives (Ibrahim and Wahyukartiningsih, 2014). The defined stage results are the main formulations of learning objectives. Students can improve their science and mathematics abilities by making experimental product design innovations as problem solving in real life.

\subsection{Design Stage}

This stage, a prototype draft of the student worksheet, was developed as draft I (Ibrahim and Wahyukartiningsih, 2014). Some of things that were done at this stage, namely the identification of facilities and infrastructure, choosing format for the preparation of the student worksheet, and the initial design of the student worksheet by looking for acid-base material which was then arranged based on the previous format (Nua et al. 2018). The student worksheet content design refers to PjBL learning and the application of STEM aspects to acid-base material. The student worksheet design in Fig 1.

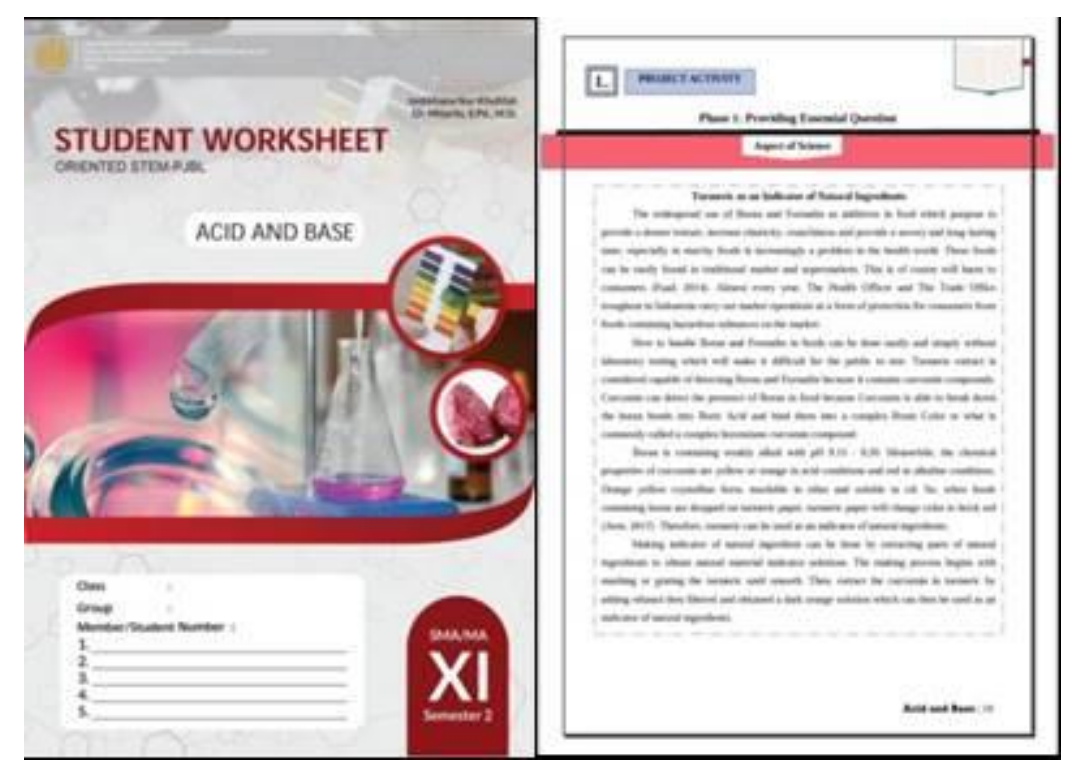

Fig 1. Draft I student worksheet; Cover (left); Example applying STEM aspect to PjBL model in student worksheet (right).

\subsection{Develop Stage}

This stage it produces a teaching material product, namely student worksheet, which is corrected based on the reviewer and validator suggestions (two chemistry lecturers and one chemistry teacher) through the validation process. The student worksheet Draft I in the previous stage was given to reviewer by with review sheet. 
The results are in the form of suggestions from reviewers as a basis to revise the student worksheet, it will produce student worksheet draft II. The following example of student worksheet revision suggestions for using background with inappropriate writing in Fig 2.
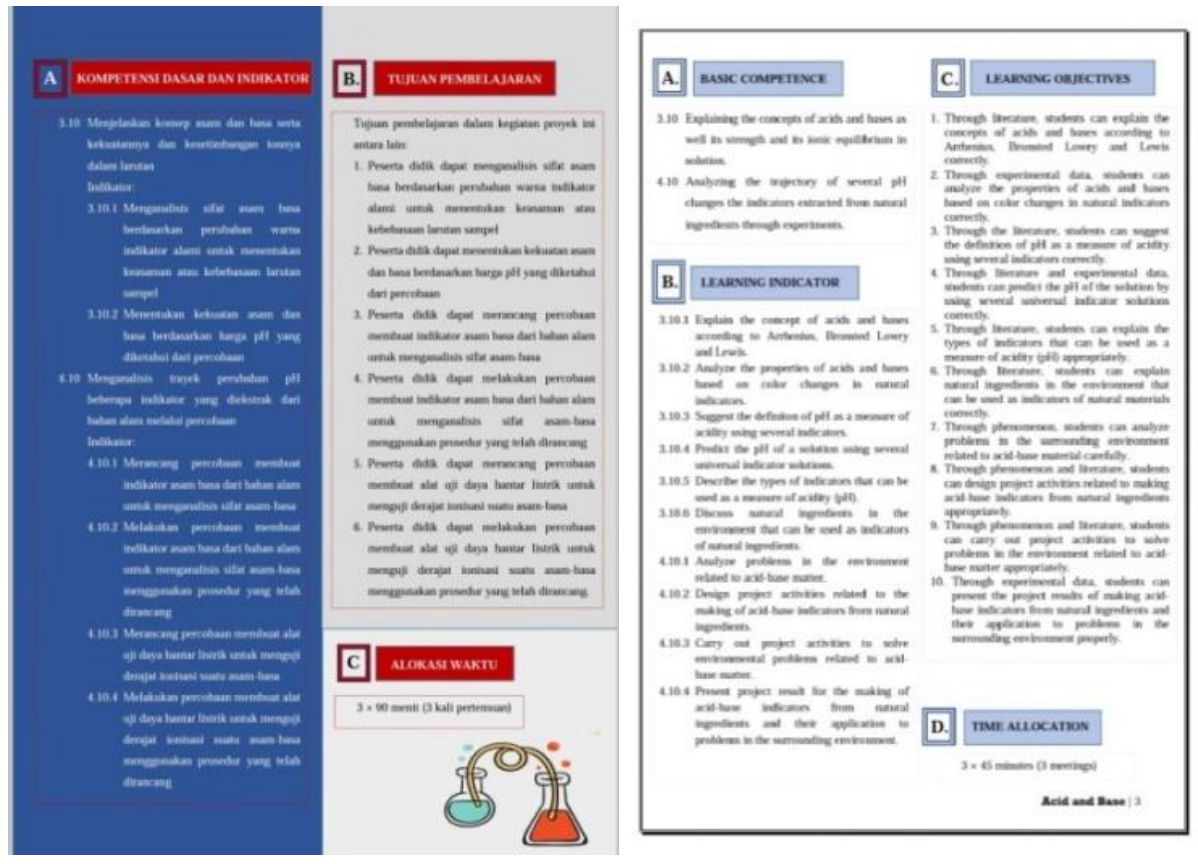

Fig 2. Example of revised student worksheet; before revision (left); after revision (right)

Student Worksheet draft II submitted to the validator to be carried out. After student worksheet declared valid, it can used for limited trials. The student worksheet products used contain all aspects of STEM. Chemistry learning with the STEM approach integrates the fields of science, technology, engineering, and mathematics (Susanti et al. 2018). Science aspects are integrated with the form of an concept explanation of acid-base material in each section and present phenomena related to applying the acid-base concept in everyday life. Students are required to identify this phenomenon by the conceptual understanding obtained in the student worksheet. With this material understanding, students are expected to combine it with technology to produce a product that can be used in people's life. Technology aspects are integrated with the explanation form of the concept application of acidbase properties using natural indicators substances. Aspect engineering is integrated with presenting information on the design of work procedures related to technology that applies acid-base concept and products resulting from project activities. In mathematics aspect, students are expected to be able to calculate the concentration of $\left[\mathrm{H}^{+}\right]$and $\left[\mathrm{OH}^{-}\right]$based on the indicated $\mathrm{pH}$. It makes it easier for students to understand the concept of acid-base and its properties. The following example student worksheet product with the STEM application aspects in Fig 3. 


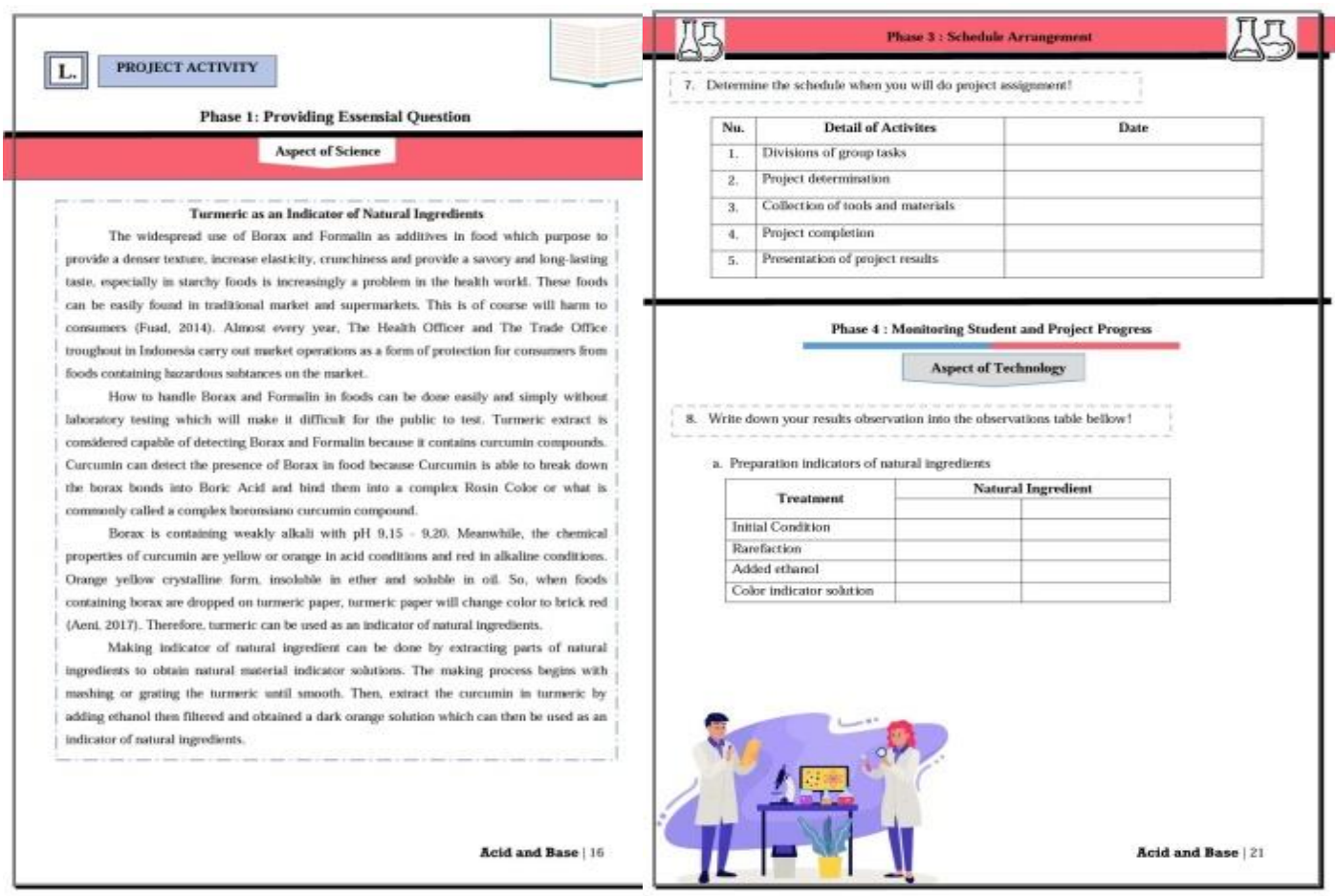

(A)

(B)

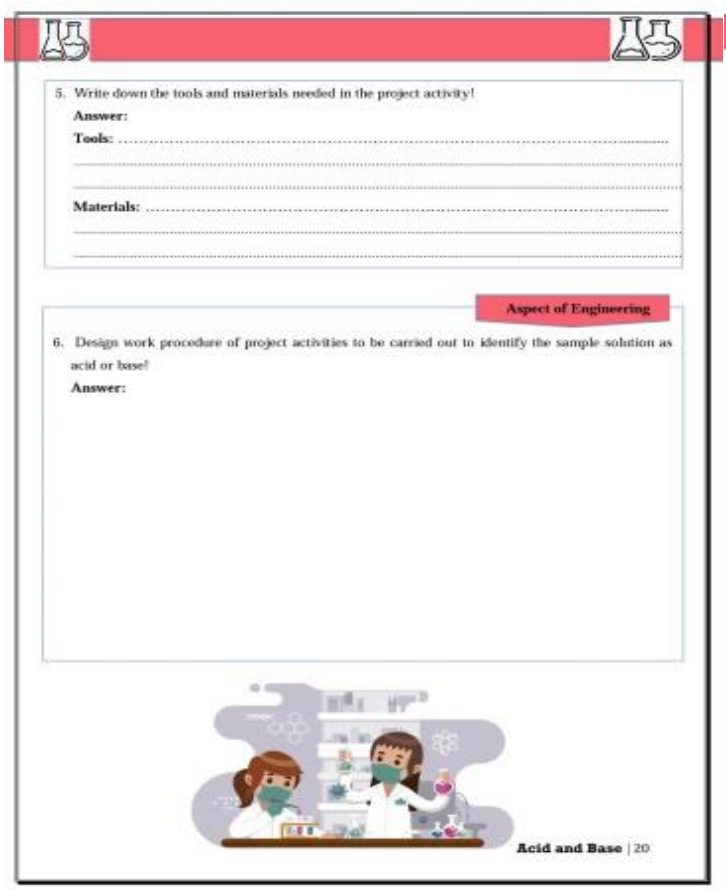

(c)

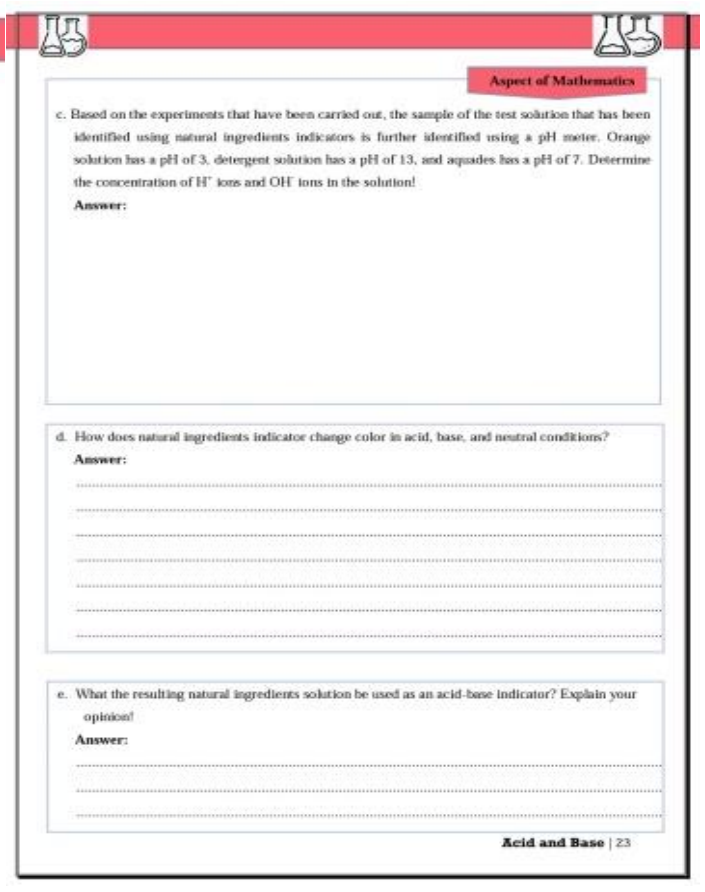

(D)

Fig 3. (A) Science Aspects (B) Technology Aspects (C) Engineering Aspects (D) Mathematics Aspects 


\subsection{Validity}

The student worksheet validity is viewed from two criteria, namely content validity and construct validity (Nieveen and Theerjd, 2010). Validation aims to determine the correctness and feasibility of student worksheet. The validity results were obtained from two chemistry lecturers and one chemistry teacher who scored through the validation sheet. The following results of student worksheet validation in Fig 4 .

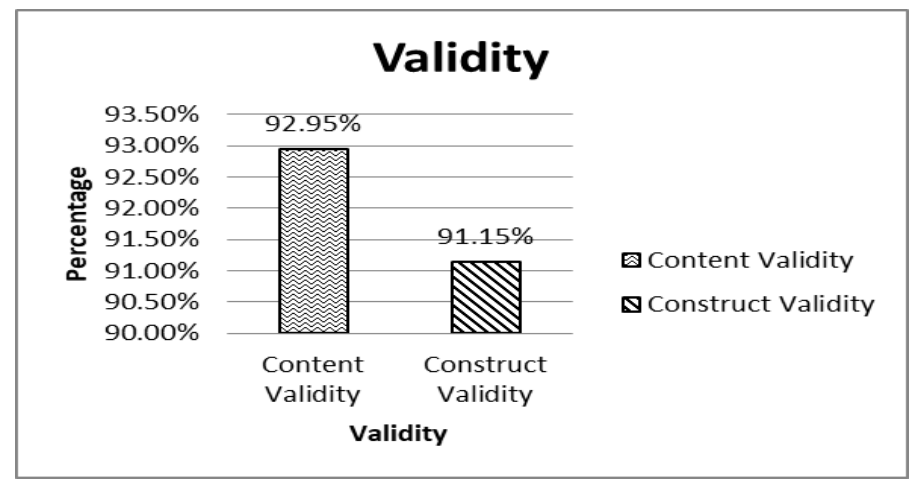

Fig 4. Student worksheet validation results

Content validity is seen from the suitability of the material with the learning objectives. The aspects contained in the content validity include (1) suitability of the material with the 2013 Curriculum, basic competencies, learning indicators and learning objectives, (2) suitability of student worksheet with the PjBL model, (3) suitability of material with practicum activities (4) and suitability of student worksheet with the STEM aspect. The validation results on the content criteria obtained an average score of $92.95 \%$ with the score interpretation by Likert scale included in very valid category. This shows that the aspects of content criteria are accordance with the 2013 Curriculum references.

Construct validity includes three criteria, namely language, presentation, and graphics to teach materials producing design can support the quality of student worksheet (Nieveen and Theerjd, 2010). The results of validation on the construct validity criteria in Fig 5 .

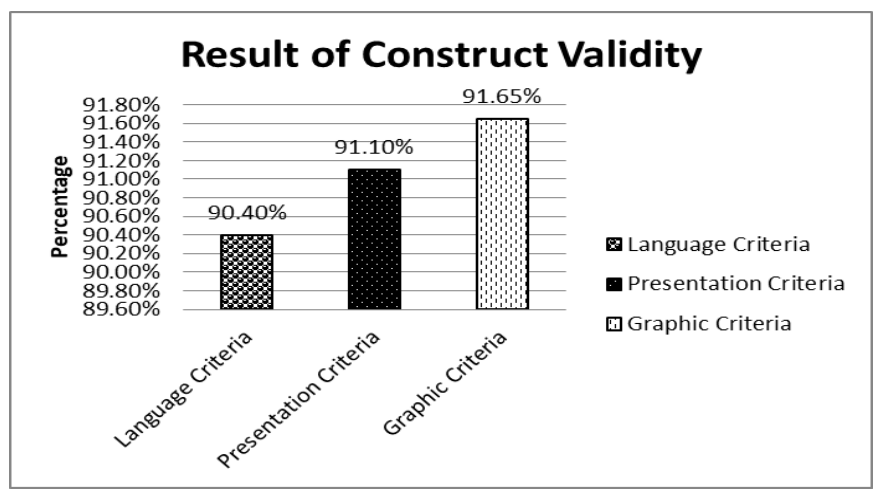

Fig 5. Construct validity results 
The mean score results obtained on the criteria for language, presentation, and graphics sequentially are $92.95 \%, 91.10 \%, 91.65 \%$, with the score interpretation on the Likert scale belong to a very valid category. The language criteria show that the language used is correct, so the information conveyed is easy for students to implement. The presentation criteria show that the information presented (covers, pictures, the order of material) is systematic and in accordance with the content of the student worksheet, it can generate motivation and students attractiveness in understanding of material being studied. Graphic criteria make it easier for students to understand and read material with several components, namely the use of fonts, layouts, images, tables, backgrounds, formulas, and appropriate writing colors (Lestari et al. 2018). After got the validity test implementation, the limited trial was conducted at SMAN 1 Gedangan by online learning to nine students of XI IPA class to obtain the practicality and effectiveness data of the STEM-PjBL student worksheet.

\subsection{Practicality}

The student worksheet practicality in results terms based on observations and questionnaires students by using student worksheet. Practicality aims to know the level of student worksheet ease when used in the learning process (Lestari et al. 2018). Activities carried out by students during learning were observed by two observers. The data generated refers to the STEM-oriented PjBL stage. The results of participant activity observations in Fig 6 .

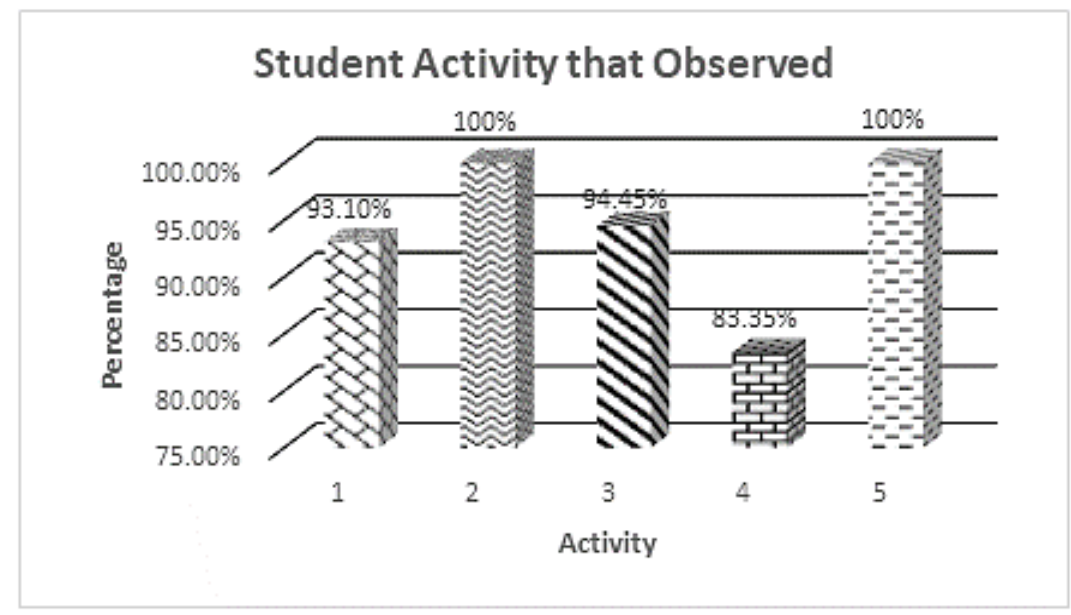

Fig 6. Student activity observation results

The activities of STEM implementation aspects with the PjBL model are categorized as follows by (1) starting essential questions, (2) assign the project, (3) create a schedule, (4) monitor students and project progress, (5) valuation and project presentation. Based on Fig 6, the students activities towards the use of student worksheet are very well developed. However, there are still activities that don't reach the maximum results shown in categories 1 and 4 with the proportions 
obtained by $93.10 \%$ and $83.35 \%$. Through this research, students are expected to be able find the information individually, so their learning is meaningfull. The third category present the proportion of acquisition of $94.45 \%$ because in the current condition with online learning, students can't properly distribute group tasks. Students in their implementation provide a project framework that can guide them find problem solutions that can complete the project according to predetermined time (Astuti et al. 2019). The effective use of time in conducting experiments shows that good cooperation between members has built (Zakiah et al. 2015) . In total, the mean proportion obtained is $95.18 \%$ with the interpretation of the score included in the very practical category (Riduwan, 2016).

After the learning process using student worksheet, students are given a response questionnaire to see the practicality student worksheet. Questionnaire participants who answered questions related to the content, presentation, and graphic criteria, language, and implementation. Fig 7 diagram showing the results of students responses.

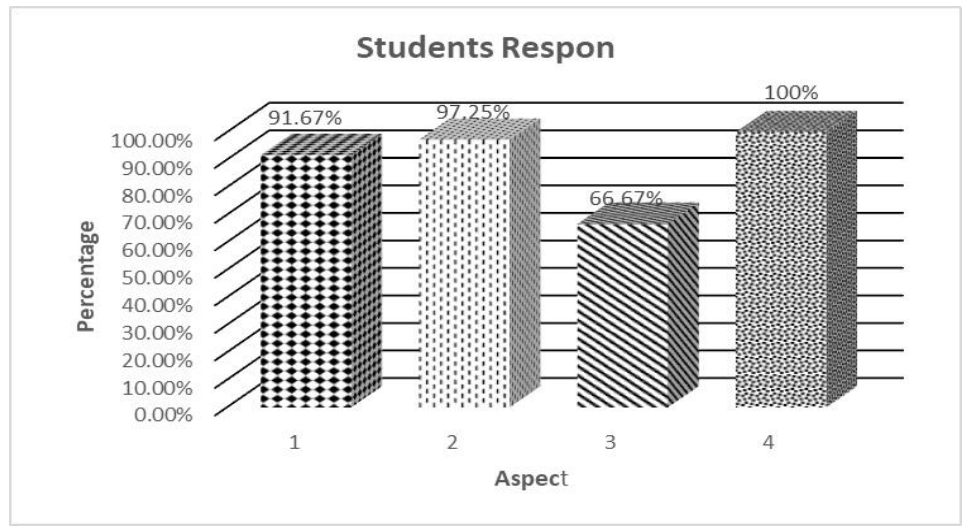

Fig 7. Student response questionnaire results

The response questionnaire results obtained on the content, presentation, and graphic, language, implementation criteria sequentially were $91.67 \%, 97.25 \%, 66.67 \%$, $100 \%$. Content criteria for students' understanding of the material on acid-base material contained in the student worksheet. This shows that the activities presentation accordance with the content criteria, thus motivating students in acidbase material learning. The presentation and graphic criteria show that the attractive student worksheet presentation makes students not bored. According Prastowo (2014) that the student worksheet design presented with a images combination and short explanations are more effective and attractive because it can convey the message or content of image as a whole (Lukman et al. 2019). It doesn't create the impression of being bored and unattractive to students. The linguistic criteria have included the use of clear and easy to apply language. Students aren't confused and don't understand the different ones, making it easier to understand the material that presented. The implementation criteria show that students in carrying out activities 
are involved and have a high curiosity. All criteria in the response questionnaire showed a mean result of $88.90 \%$ with the very practical category.

\subsection{Effectiveness}

The student worksheet effectiveness has got from the student improvement learning outcomes through the pretest and posttest scores. The pretest was given before using the developed student worksheet and the posttest was given after it. The test results are used to see the completeness of the students learning outcomes in cognitive domain by working on the questions given. Fig 8 shows the completeness of students learning outcomes.

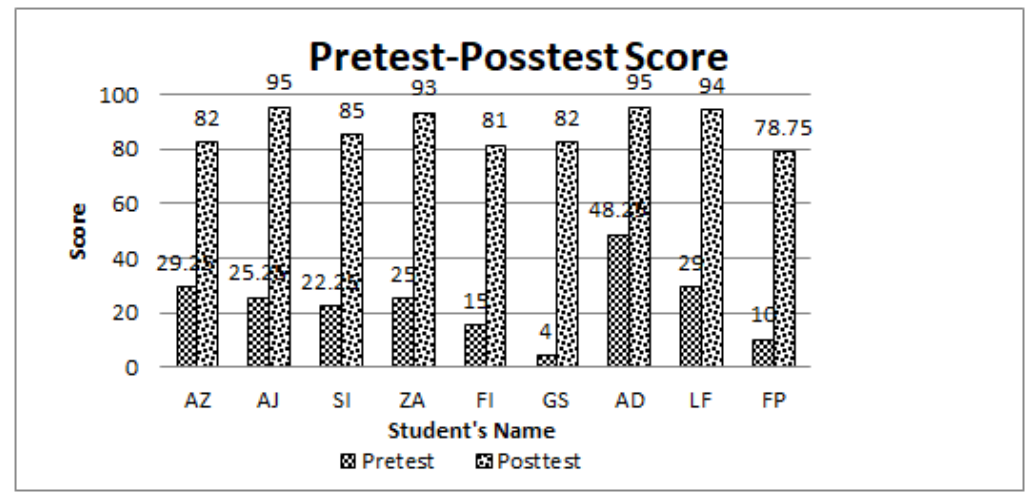

Fig 8. Students' Learning Outcomes

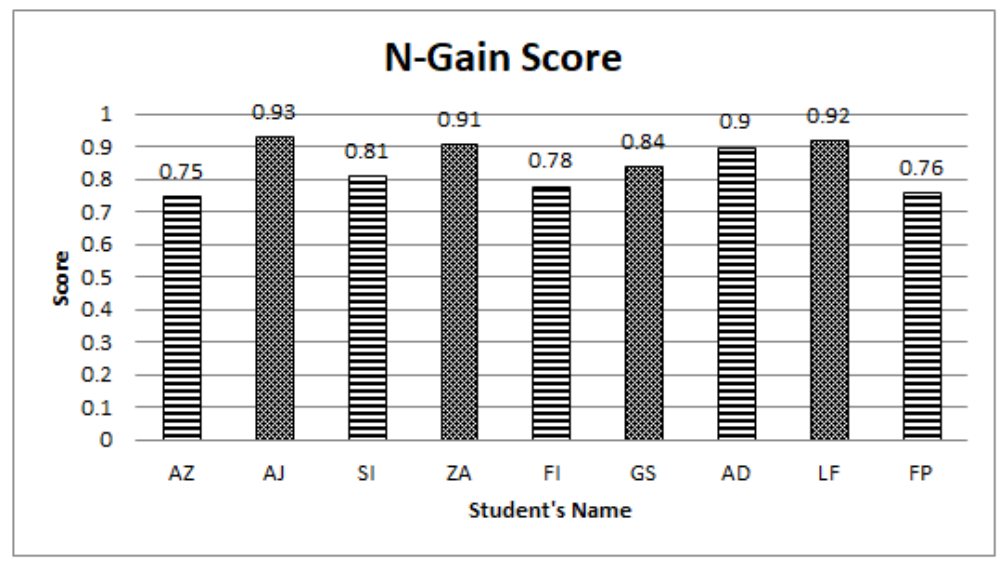

Fig 9. N-Gain Score Result

Based on Fig 8 the pretest results before using student worksheet can show that all students didn't complete with result $\leq 75$. This shows that PjBL model which integrated with STEM, can improve students' understanding of material concepts. These results are appropriate with research that conducted by Furi et al. (2018) STEM integrated PjBL model is significantly more effective in increasing the material conceptual understanding. The pretest and posttest data then analyzed using the $\mathrm{N}$ Gain score criteria that shows in Fig 9. 
Based on the $\mathrm{N}$-Gain analysis in Fig 9 shows an increase in the posttest value. The results of the average $\mathrm{N}$-Gain score obtained by students was 0.84 and included in high category. This shows that the developed student worksheet is very effective in making students more creative, critical, collaborative, and communicative (Rahmatina et al. 2020).

The students' answers evidenced this increase results in the correct posttest questions accordance with STEM aspects. Science is based on the students application to understand the basic concepts of acid-base material to identify problems in everyday life. Aspect technology is based on the students application in applying natural product indicators to identify the solution acidic properties. This research encourages high curiosity, thus influencing students to apply it directly. The engineering aspect is based on the students ability to come up with problems solving logical ideas. Students are required to plan the experiments on indicators of natural product which are acid-base in a solution. The resulting design is an innovative product development of acid-base indicators by utilizing natural product that are around. This study used natural product such as turmeric, purple cabbage, roses, and dragon fruit as depicted on Fig 10.

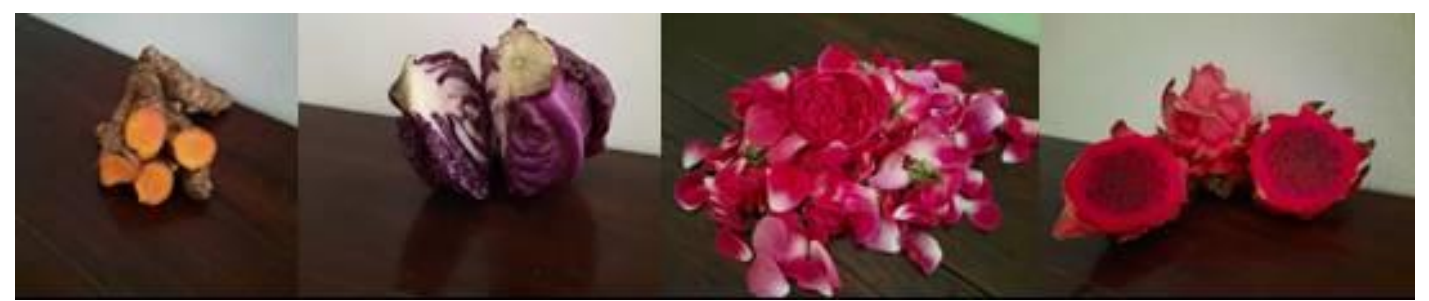

(A)
(B)
(C)
(D)

Fig 10. (A) turmeric (B) purple cabbage (C) roses (D) dragon fruit

Turmeric contains curcumin which can provide clear and rapid color changes in acidic situations by giving a light yellow color, while in alkaline conditions it gives a brownish red color (Sundari, 2016). Purple cabbage contains high anthocyanin substances and can provide clear color changes, where in an acidic atmosphere it gives a red color and the atmosphere that gives a blue color (Erwin et al. 2015). Roses and dragon fruit also contain anthocyanin substances, giving a red color change in an acidic atmosphere and give a yellow color in an alkaline atmosphere (Maryanti et al. 2011; Yulfriansyah and Novitriani, 2016). The anthocyanin substances presence give color changes to these natural product so they can be used as natural indicators. In addition, these natural product are easily found in the surrounding environment. The use of natural product, in this case, is to apply green chemistry. One of the principles of green chemistry implemented the prevention of waste, the use of damaged raw materials, and safe conditions and preventing accidents (Mitarlis et al. 2018). The Mathematic aspect of the dictionary based on students application in estimating the 
$\mathrm{pH}$ value based on the color that can be shown in the test solution is then used to calculate the concentration of $\left[\mathrm{H}^{+}\right]$and $\left[\mathrm{OH}^{-}\right]$.

The student worksheet use developed based on the STEM-PjBL makes students innovate to develop products, processes, and applications that useful solving problems in everyday life. Its is in line with Titu (2015) research, which states that the STEM integrated PjBL model is very appropriate to be applied in learning because it can increase student learning activities in completing a project that applied in everyday life.

\section{Conclusion}

Based on data analysis and discussion of research results, it can be concluded that the developed student worksheet oriented on STEM with project-based learning model is feasible in terms of validity, practicality, and effectiveness. Validity that includes content and constructs validity (language, presentation, and graphics) obtains a very valid category score. The practicality of student worksheets in terms of activity observations and students' responses obtained scores in the very practical category. The student worksheet's effectiveness in terms of the completeness of the learning outcomes of students showed an increase in the average N-Gain score with a very high category and was effective to use. So, the developed students worksheet oriented to STEM with PjBL model on acid base matter by using natural product is feasible for use in the learning.

\section{References}

Afriana, J., Permanasari, A., and Fitriani, A. (2016). Penerapan project based learning terintegrasi STEM untuk meningkatkan literasi sains siswa ditinjau dari gender. Jurnal Inovasi Pendidikan IPA, 2(2), 202-212. DOI: 10.21831/jipi.v2i2.8561

Astuti, I. D., Toto, T., and Yulisma, L. (2019). Model project based learning (PjBL) terintegrasi STEM untuk meningkatkan penguasaan konsep dan aktivitas belajar siswa. Quangga: Jurnal Pendidikan dan Biologi, 11(2), 93-98. DOI: 10.25134/quagga.v11i2.1915

Bybee, R. W. (2013). The case for STEM education: Challenges and Opportunity. Arlington, VI: National Science Teachers Association Press.

Depdiknas. (2008). Panduan pengembangan bahan ajar. Jakarta: Direktorat Jenderal Manajemen Pendidikan Dasar dan Menengah.

Erwin, Nur, M. A., and Panggabean, A. S. (2015). Potensi pemanfaatan ekstrak kubis ungu (Brassica oleracea L.) sebagai indikator asam basa alami. Jurnal Kimia Mulawarman, 13(1), 15-18.

Furi, L. M. I., Handayani, S., \& Maharani, S. (2018). Eksperimen model pembelajaran project based learning dan project based learning terintegrasi stem untuk mengingkatkan hasil belajar dan kreativitas siswa pada kompetensi dasar teknologi pengolahan susu. Jurnal Penelitian Pendidikan, 35(1), 49-60. DOI: 10.15294/jpp.v35i1.13886

Hake, R. R. (1999). Interactive engagement versus traditional methods: A six thousand 
student survey of mechanics test data for introductory physics courses. American Journal of Physics, 66(1), 64-67.

Harefa, N., Silalahi, N.F.D., Sormin, E., Sanga Purba, L.S.L., \& Sumiyati, S. (2019). The difference of students' learning outcomes with project based learning using handout and sway Microsoft 365. Jurnal Pendidikan Kimia, 11(2), 24-30. DOI: 10.24114/jpkim.v11i2.14459

Hendayana, Y. (2020). Tantangan dunia pendidikan di masa pandemi, Kementerian Pendidikan dan Kebudayaan. Retrivied December 17, 2020, from https://dikti.kemdikbud.go.id/kabardikti/kabar/tantangan-dunia-pendidikan-di-masa-pandemi/

Ibrahim, M., and Wahyukartiningsih. (2014). Model pembelajaran melalui pemaknaan. Surabaya: Unesa Press.

Kemendikbud. (2018). Permendikbud No.36 Tahun 2018 tentang Perubahan Peraturan Kurikulum 2013. Jakarta: Kemendikbud (pp. 1-12).

Lestari, L., Alberida, H., and Rahmi, Y. L. (2018). Validitas dan praktikalitas lembar kerja peserta didik (LKPD) materi kingdom plantae berbasis pendekatan saintifik untuk peserta didik kelas X SMA/MA. Jurnal Eksakta Pendidikan, 2(2), 170-177. DOI: 10.24036/jep/vol2-iss2/245

Lukman, I., Damanik, M., Silaban, S., \& Kembaren, A. (2019). Development of problem based learning innovative student worksheets in learning the concept of chemistry for senior high school students. Journal of Transformative Education and Educational Leadership, 1(1), 23-28.

Maryanti, E., Trihadi, B., and Ikhwanuddin. (2011). Pemanfaatan ekstrak bunga mawar merah (Rosa hibrida bifera) sebagai indikator pada titrasi asam basa. Jurnal Gradien, 7(2), 697701.

Melania, E. P. (2020). Pembelajaran Berani, Apakah Efektif untuk Indonesia?. Kompas. Retrivied January 20, 2021, from https://muda.kompas.id/baca/2020/04/06/pembelajarandaring-apakah-efektif-untuk-indonesia/

Mitarlis, S., Ibnu, S., Rahayu, S., \& Sutrisno, Sutrisno. (2020). The effectiveness of new inquiry-based learning (NIBL) for improving multiple higher-order thinking skills (MHOTS) of prospective chemistry teachers. European Journal of Educational Research, 9(3), 1309-1325. DOI: 10.12973/eu-jer.9.3.1309

Mitarlis, Azizah, U., and Yonatha, B. (2018). Pemanfaatan indikator alam dalam mewujudkan pembelajaran kimia. Jurnal Penelitian Pendidikan IPA, 3(1), 1-7.

Mulyani, T. (2019). Pendekatan pembelajaran STEM untuk menghadapi revolusi. Seminar Nasional Pascasarjana 2019, 453-460.

Nieveen, N., and Theerjd, P. (2010). An introduction to educational design research enscede. SLO: Netherland Institute for Curriculum Development.

Ningtyas, P. K., Widarti, H. R., and Ibnu, M. S. (2019). Pengembangan bahan ajar dengan pendekatan STEM PjBL berbasis kontekstual pada materi asam dan basa untuk siswa kelas XI SMA/MA. Prosiding Seminar Nasional Kimia dan Pembelajarannya (SNKP), 373-381.

Nua, M. T. P., Wahdah, N., and Mahfud, M. (2018). Pengembangan lembar kerja peserta didik (LKPD) K-13 berbasis discovery learning siswa SMA kelas X pada materi analisis vektor. Jurnal Nalar Pendidikan, 6(2), 95-104.

OECD. (2018). PISA 2018 Result-Combined Executive Summaries Volume I, II \& 3. Retrivied January 16, 2020, from https://www.oecd.org/pisa/Combined_Executive_Summaries_PISA_2018.pdf 
Permanasari, A. (2016). STEM education: Inovasi dalam pembelajaran sains. Prosiding Seminar Nasional Pendidikan Sains (SNPS), 23-34.

Prastowo, A. (2014). Panduan kreatif membuat bahan ajar inovatif: Menciptakan metode pembelajaran yang menarik dan menyenangkan. Yogyakarta: Diva Press.

Pratiwi, S. N., Cari, C., and Aminah, N. S. (2019). Pembelajaran IPA abad 21 dengan literasi sains siswa. Jurnal Materi dan Pembelajaran Fisika (JMPF), 9(1), 34-42.

Rahmatina, C. A., Jannah, M., and Annisa, F. (2020). Pengembangan bahan ajar berbasis STEM (science, technology, engineering, and mathematics) di SMA/MA. Jurnal Pendidikan Fisika dan Fisika Terapan, 1(1), 27-33. DOI: 10.22373/p-jpft.v111.6531

Riduwan. (2016). Skala pengukuran variabel-variabel penelitian. Bandung: Alfabeta.

Sadikin, A., and Hamidah, A. (2020). Pembelajaran daring di tengah wabah covid-19. Biodik, 6(2), 214-224. DOI: 10.22437/bio.v6i2.9759

Silaban, S. (2021). Pengembangan program pengajaran. Medan: Yayasan Kita Menulis.

Slavin, R. E. (2011). Psikologi pendidikan. Jakarta: PT. Indeks.

STEM, I. (2020). ISLE Based STEM Education. Retrivied December 17, 2020, from https://stem.id/about-us/

Sundari, R. (2016). Pemanfaatan dan efisiensi kurkumin kunyit (Curcuma domestica VAL) sebagai indikator titrasi asam basa. (2016). Teknoin, 22(8), 595-601. DOI: 10.20885/teknoin.vol22.iss8.art5

Susanti, L. Y., Hasanah, R., \& Khirzin, M. H. (2018). Penerapan media pembelajaran kimia berbasis science, technology, engineering, and mathematics (STEM) untuk meningkatkan hasil belajar siswa SMA/ SMK pada materi reaksi redoks. Jurnal Pendidikan Sains (JPS), 6(2), 32. DOI: 10.26714/jps.6.2.2018.32-40

Titu, M. A. (2015). Penerapan model pembelajaran project based learning (PjBL) untuk meningkatkan kreativitas siswa pada materi konsep masalah ekonomi. Prosiding Seminar Nasional Pendidikan Ekonomi FE UNY, 176-186.

Wahyono, P., Husamah, H., and Budi, A. S. (2020). Guru profesional di masa pandemi COVID19: Review implementasi, tantangan. Jurnal Pendidikan Profesi Guru, 1(1), 51-65. DOI: 10.22219/jppg.v111.12462

Wisudawati, A. W. (2018). Science technology engineering and mathematics (STEM) education approach against a microscopic representation skill in atom and molecule concept. International Journal of Chemistry Education Research, 2(1), 1-5. DOI: 10.20885/ijcer.v2i1.10067

Witri, E., Ngatijo, N., \& Haris Effendi-Hasibuan, M. (2020). Development of electronic student worksheets based on toulmin argumentation patterns to improve argumentation skills in basic acid materials. Jurnal Pendidikan Kimia, 12(3), 116-123. DOI: 10.24114/jpkim.v12i3.21160

Yulfriansyah, A., \& Novitriani, K. (2016). Pembuatan indikator bahan alami dari ekstrak kulit buah naga (hylocereus polyrhizus) sebagai indikator alternatif asam basa berdasarkan variasi waktu perendaman. Jurnal Kesehatan Bakti Tunas Husada, 16(1), 153. DOI: 10.36465/jkbth.v16i1.178

Zakiah, Z., Silalahi, A., \& Muchtar, Z. (2015). Pengembangan penuntun praktikum tipe discovery dan tipe project based learning pada pembelajaran elektrolit dan non elektrolit di SMA. Jurnal Pendidikan Kimia, 7(1), 83-94. 